\title{
Revision of the palearctic Onychiurus species of obsiones group (Collembola: Onychiuridae)
}

\begin{abstract}
I.J. Kaprus'
State Museum of Natural History of NAS of Ukraine, Teatral'na Str. 18, 79008 L'viv, Ukraine. e-mail:i-kaprus@mail.ru

ABSTRACT: Three new species, Onychiurus orienteuropeus sp.n., Onychiurus jaceki sp.n. and Onychiurus sarmaticus sp.n. are described from Ukraine, Armenia and Kyrgyzstan. Onychiurus obsiones Cassagnau, 1963, Onychiurus vtorovi Martynova, 1976 and Onychiurus darii Pomorski, 1998 are re-described based on the type specimens and new material. An identification key to all the palearctic species of the obsiones group of the genus Onychiurus is provided.
\end{abstract}

KEY WORDS: springtails, taxonomy, Onychiurus.

\section{Ревизия палеарктических видов Onychiurus группы obsiones (Collembola: Onychiuridae)}

\section{И.Я. Капрусь}

Государственный природоведческий музей НАН Украины, ул. Театральная, 18, Львов 79008 , Украина.

e-mail: i-kaprus@mail.ru

РЕЗЮМЕ: Описано три новых для науки вида: Onychiurus orienteuropeus sp.n., Onychiurus jaceki sp.n. and Onychiurus sarmaticus sp.n. из Украины, Армении и Киргизстана. На основании изучения типовых экземпляров и новых материалов переописаны Onychiurus obsiones Cassagnau, 1963, Onychiurus vtorovi Martynova, 1976 и Onychiurus darii Pomorski, 1998. Приведен ключ для определения всех видов Onychiurus группы obsiones.

КЛЮЧЕВЫЕ СЛОВА: Ногохвостки, таксономия, Onychiurus.

\section{Introduction}

The genus Onychiurus was firstly described by Gervais (1841). Later, Weiner (1996) reestablished the genus Onychiurus in the narrow sense. Now, the genus Onychiurus Gervais, 1841 sensu Weiner 1996 contains 40 species (Bellinger et al., 1996-2008). This genus is characterized by the following diagnostic characters: postantennal sense organ with

Printed in 2009. compound vesicles, antennal III sense organ with 2 smooth sensory clubs, furca reduced to a small area of fine granulation with $2+2$ posterior setulae arranged in a row, tibiotarsi with distal whorl composed of 7 or 9 setae, seta d0 on a head and anal spines present (Weiner, 1996; Pomorski, 1998a).

There is a group of palearctic Onychiurus species that are characterized by small body size (up to $1 \mathrm{~mm}$ ) and dorsal pseudocellar formula: 32/033/33333, ventral: 2/000/0001. The spe- 
cies of this group occurs in arid and semiarid regions of the Palearctic: South-East Europe (O. darii), Middle Asia (O. vtorovi) and North Africa (O. obsiones).

During the study of the collembolan fauna of South Ukraine, two new species of the obsiones species group were found. Additional material collected in Kyrgyzstan also contained a new species of this group. The type specimens of $O$. obsiones, $O$. vtorovi, and $O$. darii has been also examined for comparison.

The present paper provides a review of all known palearctic members of the obsiones species group of Onychiurus, including redescriptions of three known species and descriptions of three new species from Ukraine, Armenia and Kyrgyzstan. The examination of the new findings enables to compile the identification key to all the species of this group.

In the present paper, I follow the morphological nomenclature and the rules of description suggested by Pomorski (1998).

\section{Material and methods}

The specimens were collected in Dnipropetrovsk and Kherson districts and steppe zone of Crimean Peninsula (Ukraine), Republic of Tuva (Russian Federation), mountain steppes of Armenia and Issyk Kul Lake region (Kyrgyzstan). Soil samples were taken by metal auger and extracted for five days in a modified Tulgren's apparatus. Material was fixed in $80 \%$ ethanol. The springtails were then placed into Faure's solution for study and identification.

Type material from collections of the Zoological Institute of Russian Academy of Sciences (St.-Petersburg), Museum of Natural History (Paris) and Zoological Institute of Wroclaw University (Poland) was also examined.

Material is deposited in the following scientific institutions: IEEM — Institute of Ecology and Evolution of Russian Academy of Sciences, Moscow; MC - Zoological Institute of Russian Academy of Sciences, St.-Petersburg (Martynova Collection); SNHMU — State Natural History Museum of Ukrainian National Academy of Sciences, L'viv; MNHNF - Museum of
Natural History, Paris;ZIWU - Department of Biodiversity and Evolutionary Taxonomy, Zoological Institute, Wroclaw University, Poland.

\section{Taxonomy}

Onychiurus vtorovi Martynova, 1976

Figs 1A-K, 2D, K.

Material examined. Paratypes: 3 females on slides, Kyrgyzstan, near Issyk Kul Lake, Kok-Moinok locality, $1580 \mathrm{~m}$ alt., soil underArtemisia, 23.07.1969, leg. P.Vtorov (MC).

Other material examined. 2 males and 1 female on slides, Kyrgyzstan, Issyk Kul district, Karakol area, Dzhety Oguz, $2600 \mathrm{~m}$ alt., plant debris with gravel near stream, 11.06.2006, leg. R.J. Pomorski; 1 male and 3 female on slides, Kyrgyzstan, $200 \mathrm{~km}$ from border of the Issyk Kul Lake, Bozteri, roots of sedges and grasses, 07.06.2006, leg. R.J. Pomorski; 4 males and 5 females on slides, Russia, South Tuva, Ubsu-Nur Basin, ca 15 km NE bank of Ubsu-Nur Lake and $5 \mathrm{~km}$ to Akchara environs, semidesert steppe with Nanophyton grubovi and Stipa glareosa, $1100 \mathrm{~m}$ alt., 17.07.1993, leg. S.K. Stebaeva; 2 females on slide, Russia, South Tuva, Ubsu-Nur Basin, ca $10-15 \mathrm{~km}$ SE Erzyn, NE bank of Tore-Khol' Lake, $50^{\circ} 03^{\prime} \mathrm{N}$ $95^{\circ} 08^{\prime} \mathrm{E}, 1100 \mathrm{~m}$ alt., small humid birch forest among sands, in litter and soil, 12.06.1995, leg. S.K. Stebaeva (SNHMU, ZIWU and IEEM).

Redescription. Body length (without antennae) 0.80-1.00 mm. Colour yellowish on slides. Body shape cylindrical (Fig. 1A). Granulation of body uniform and fine, antennal bases are not marked. Antennal segment IV with subapical organite (Fig. 1B). Microsensillum on antennal segment IV is situated in the triangle formed by $\mathrm{a}, \mathrm{b}$ and $\mathrm{c}$ chaetae (Figs 1D, 2D). Antennal III sense organ built of 5 guard setae, 4 papillae, 2 smooth sensory clubs and 2 small sensory rods (Figs 1D, F). Postantennal sense organ small, ca. 3.3 times as long as the nearest pseudocellus with 9-10 finely granulated vesicles (Figs $1 \mathrm{G}, \mathrm{H}$ ).

Dorsal pseudocellar formula 32/033/33333, ventral 2/000/00010; all subcoxa 1 with one pseudocellus and one parapseudocellus (Figs 1A, K). Formula parapseudocelli ventrally: 0/000/111000 (Fig. 1K). Labium A type (Fig. 1C). Maxillary palp simple (Fig. 1E).

Dorsal chaetotaxy nearly symmetrical, poorly differentiated into macro- and microchaetae (Fig. 1A). Sensilla relatively long and weakly differentiated on dorsal side of body. The shape and relative length of some sensilla, ordinary setae and anal spine given in Fig. 1J. Sensillar formula dorsally 1/011/ 111121. Thoracic terga II and III with lateral microsensilla. Head with seta d0. Thoracic tergum I with $6+6$ setae. Abdominal tergum IV with or without medial seta $\mathrm{m} 0$. Setae $\mathrm{a} 2$ present and setae $\mathrm{m} 2$ absent on abdominal tergum V (Fig. 2K). Abdominal tergum VI with one medial seta p0. Anal spines relatively strong, about 1.00-1.27 of inner edge of the length of 


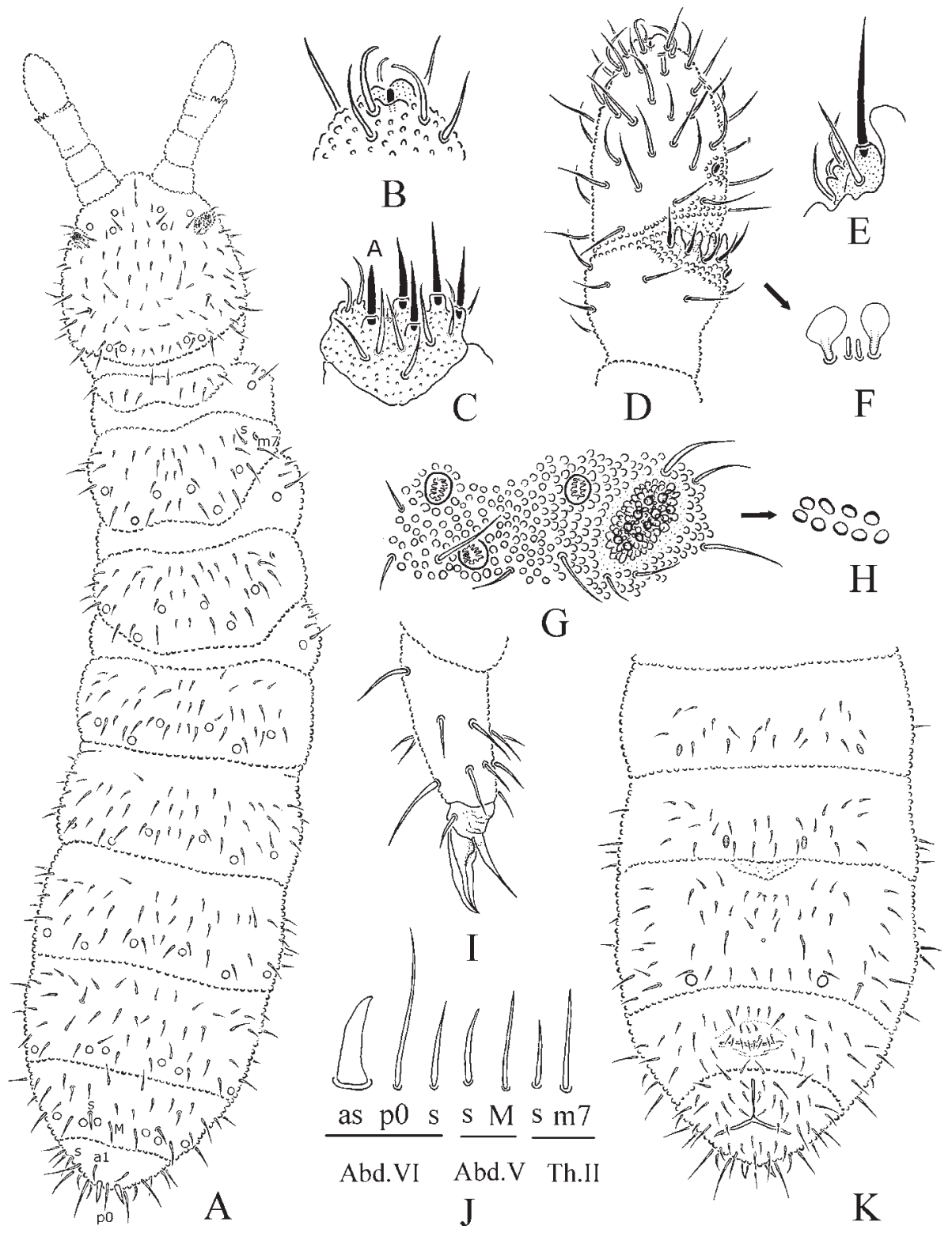

Fig. 1. Onychiurus vtorovi Martynova, 1976.

A - habitus and dorsal chaetotaxy, B - tip of antenna with subapical organite, C - labial palp, D - antennal segments III and IV with antennal III sense organ, E - maxillary palp, F - sensory clubs and sensory rods, G - postantennal organ and anterior cephalic pseudocelli, $\mathrm{H}$ - arrangement of bases of vesicles in postantennal organ, I - tibiotarsal chaetotaxy and claw of leg III, J - dorsal ordinary setae (m7, M, p0) and sensilla (s) set and anal spine (as), K - chaetotaxy of abdominal sterna II-VI.

Рис. 1. Onychiurus vtorovi Martynova, 1976.

$\mathrm{A}$ - общий вид и дорсальная хетотаксия, В - апикальная часть усика с субапикальным органитом, C максилярный щупик, D - III и IV сегменты усика с антеннальным органом, E - лабиальная пальпа, F сенсорные колбочки и сенсорные палочки, $\mathrm{G}$ - постантеннальный орган и ложные глазки в основании усиков, $\mathrm{H}$ - основания везикул в постантеннальном органе, I - хетотаксия тибиотарзуса и коготок третей ноги, J набор обычных дорсальных хет (m7, M, p0) и сенсилл (s), а также анальный шип (as), K — хетотаксия II-VI абдоминальных стернитов. 
Table. Morphological characteristics and geographical distribution of species belonging to the obsiones group of the genus Onychiurus.

Таблица. Морфологические характеристики и географическое распространение видов группы

"obsiones" рода Onychiurus.

\begin{tabular}{|l|c|c|c|c|c|c|}
\hline Species & $\begin{array}{c}\text { Onychiurus } \\
\text { obsiones } \\
\text { Cassagnau, } \\
1963\end{array}$ & $\begin{array}{c}\text { Onychiurus } \\
\text { vtorovi } \\
\text { Martynova, } \\
1976\end{array}$ & $\begin{array}{c}\text { Onychiurus } \\
\text { darii } \\
\text { Pomorski, } \\
1998\end{array}$ & $\begin{array}{c}\text { Onychiurus } \\
\text { orienteuropeus } \\
\text { sp.n. }\end{array}$ & $\begin{array}{c}\text { Onychiurus } \\
\text { sarmaticus } \\
\text { sp.n. }\end{array}$ & $\begin{array}{c}\text { Onychiurus } \\
\text { jaceki } \\
\text { sp.n. }\end{array}$ \\
\hline Size, mm & $0.60-0.80$ & $0.80-1.00$ & $0.66-0.90$ & $0.73-0.91$ & $0.67-0.77$ & $0.85-0.95$ \\
\hline $\begin{array}{l}\text { Number papillae in } \\
\text { Ant. III organ }\end{array}$ & 5 & 4 & 4 & 5 & 5 & 5 \\
\hline $\begin{array}{l}\text { Number guard setae in } \\
\text { Ant. III organ }\end{array}$ & 4 & 5 & 5 & 4 & 5 & 5 \\
\hline $\begin{array}{l}\text { Number setae on } \\
\text { thoracal tergum I }\end{array}$ & $6+6$ & $6+6$ & $6+6$ & $6+6$ & $6+6$ & $7+7$ \\
\hline $\begin{array}{l}\text { Number setae on } \\
\text { subcoxae1 of I,II,III } \\
\text { legs }\end{array}$ & $2,3,4$ & $2,4,4$ & $2,3-4,3-4$ & $2,3,3$ & $3,4,4$ & $3,4,4$ \\
\hline $\begin{array}{l}\text { Seta m0 on abdominal } \\
\text { tergum IV }\end{array}$ & absent & $\begin{array}{c}\text { or } \\
\text { absent }\end{array}$ & $\begin{array}{c}\text { obsent } \\
\text { present / } \\
\text { absent }\end{array}$ & $\begin{array}{c}\text { present / } \\
\text { absent }\end{array}$ & $\begin{array}{c}\text { absent / } \\
\text { present }\end{array}$ & present / \\
absent & present / \\
absent
\end{tabular}

claw III (Fig. 1J). Subcoxa 1 of I, II, III pairs of legs with 2, 4, 4 setae respectively (Fig. 1A).

Ventral chaetotaxy of abdominal sterna II-VI as on Fig. 1K: $0+0,1+1$ and $1+1$ ventral setae on pro-, meso- and metathorax respectively. Ventral tube with $6+6$ laterodistal setae and without setae at the base. Furca reduced to small area of fine granulation with $2+2$ setulae posteriorly arranged in one row (Fig. 1K).

Claws without inner tooth. Empodial appendage as long as inner edge of the claw, without basal lamella (Fig. 1I). Tibiotarsi with distal whorl composed of 7 setae. Male ventral organ absent.

Taxonomic remarks. Onychiurus vtorovi was described by Martynova in Vtorov, Martynova (1976) on the base of many specimens from the Issyk Kul Lake Basin (Kyrgyzstan). Examination of three paratypes let me ascertain that this species belongs to the obsiones group and is closely related to $O$. darii Pomorski, 1998. It differs from $O$. darii in the absence of parapseudocelli on abdominal sterna $\mathrm{V}$ and VI, in stronger anal spines and in the position of microsensillum on antennal segment IV (see Table).

Biology. O. vtorovi is bisexual species. It inhabits mountainous xerophytic steppes of South Siberia and Kyrgyzstan.

Onychiurus darii Pomorski, 1998

Figs 2A-C, E, I, F.

Material examined. Paratypes: 3 females on slides: Bulgaria, Cernomorec near Burgas, sand dunes and lichens, 04.09.1996, leg. D. Skarzynski (ZIWU). 


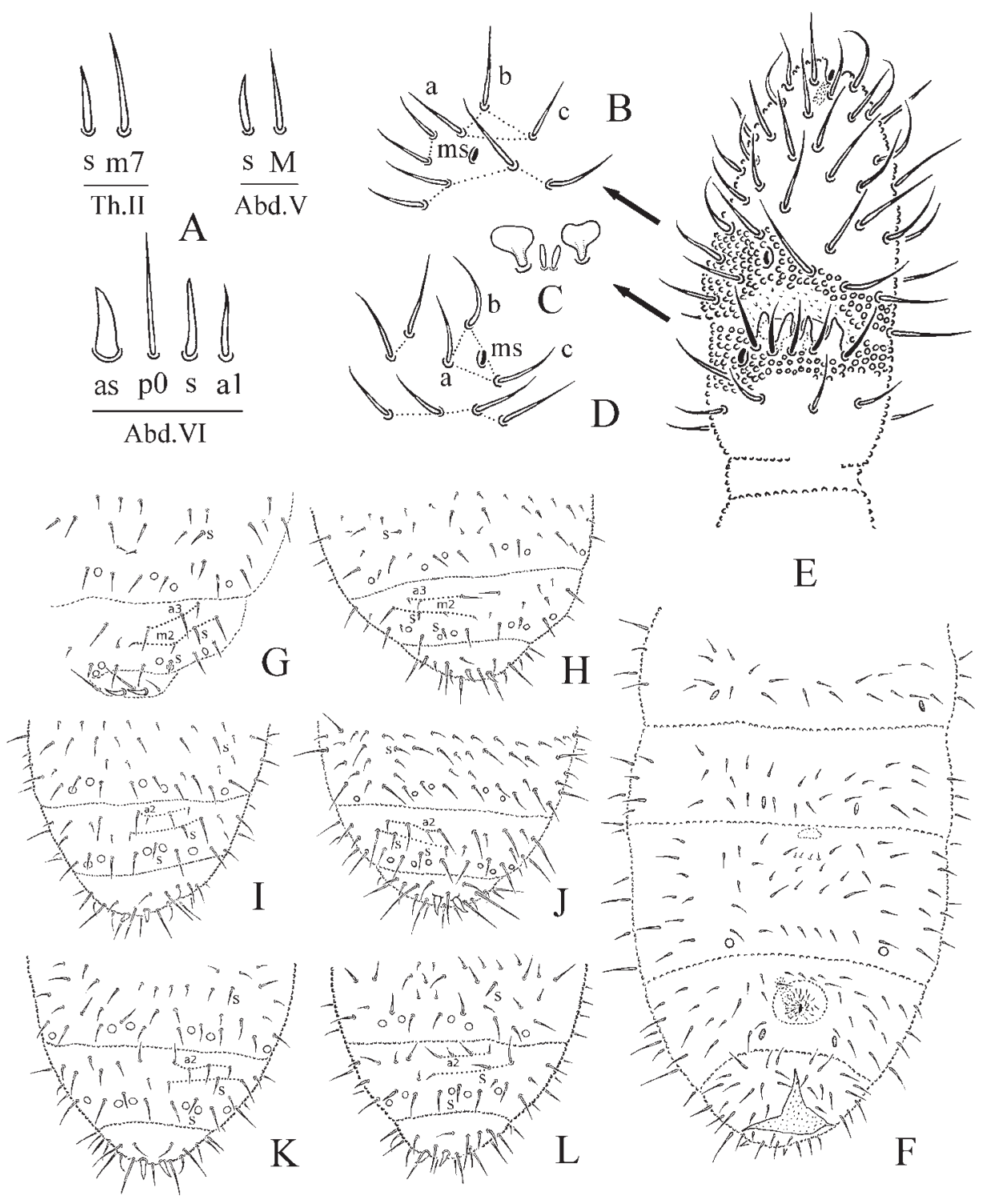

Fig. 2. A-C, E, F, I. Onychiurus darii Pomorski, 1998; D, K. Onychiurus vtorovi Martynova, 1976; G. Onychiurus obsiones Cassagnau, 1963; H. Onychiurus orienteuropeus sp.n.; J. Onychiurus jaceki sp.n.; L. Onychiurus sarmaticus sp.n.

A - dorsal ordinary setae ( $\mathrm{m} 7, \mathrm{M}, \mathrm{p} 0, \mathrm{a} 1)$ and sensilla (s) set and anal spine (as), B - location of microsensillum (ms) on antennal segment IV, C - sensory clubs and sensory rods, D - location of microsensillum (ms) on antennal segment IV, E - antennal segments III and IV with antennal III sense organ, F - chaetotaxy of abdominal sterna II-VI, G-L chaetotaxy of abdominal terga IV-VI.

Рис. 2. А-С, Е, F, I. Onychiurus darii Pomorski, 1998; D, K. Onychiurus vtorovi Martynova, 1976; G. Onychiurus obsiones Cassagnau, 1963; H. Onychiurus orienteuropeus sp.n.; J. Onychiurus jaceki sp.n.; L. Onychiurus sarmaticus sp.n.

A - набор обычных дорсальных хет (m7, M, p0, a1) и сенсилл (s), а также анальный шип (as), В — локализация микросенсиллы (ms) на IV сегменте усика, C - сенсорные колбочки и сенсорные палочки, D - локализация микросенсиллы (ms) на IV сегменте усика, E - III и IV сегменты усика с антеннальным органом, F — хетотаксия II-VI абдоминальных стернитов, G-L - хетотаксия IV-VI абдоминальных тергитов. 
Other material examined. 14 males and 19 females on slides, Ukraine, Kherson district, Hola Prystan' town, Chornomorsky Reservation, "Volyzhyn lis" locality, steppe, near pond, sandy soil, 29.04.2006, leg I. Kaprus' (SNHMU).

Additional description. Body length (without antennae) $0.66-0.90 \mathrm{~mm}$. Antennal segment IV with microsensillum, situated outside the triangle formed by a, b, c setae (Figs 2B, E). Antennal III sense organ built of 5 guard setae, 4 papillae, 2 smooth sensory clubs and 2 small sensory rods (Figs 2C, E). Postantennal sense organ small with 9-10 finely granulated vesicles. Labium A type. Ventral parapseudocellar formula 0/000/111011 ${ }^{\mathrm{m}}$ (Fig. 2F). Each subcoxa 1 with one pseudocellus and one parapseudocellus. Sensilla feebly differentiated on body. The shape and relative length of some sensilla, ordinary setae and anal spine given in Fig. 2A. Dorsal sensillar formula 1/011/111121. Thoracic tergum I with 6+6 setae. Abdominal tergum IV with medial seta $\mathrm{m} 0$ (seldom lacking). Setae a2 present and setae $\mathrm{m} 2$ absent on abdominal tergum V (Fig. 2I). Abdominal tergum VI with one medial seta $\mathrm{p} 0$. Anal spines relatively short, about $0.66-1.00$ of length of inner edge of the claw III (Fig. 2A). Subcoxa 1 of I, II, III pairs of legs with 2, 3-4, 3-4 setae respectively.

Remarks. Onychiurus darii was recently described by Pomorski (1998) from Bulgaria. Examination of the type specimens and Bulgarian and Ukrainian material enables to add some new morphological characters to the original description. $O$. darii is closely related to $O$. vtorovi Martynova, 1976 (for differences between these two species see Table and remarks to the redescription of $O$. vtorovi).

Biology. O. darii is bisexual species. It has been collected on dry meadow and sand dunes near the Black Sea coast. It probably prefers sandy soil.

Onychiurus obsiones Cassagnau, 1963

Figs 2B, G.

Material examined. Paratypes: 2 females on slide (both specimens in a bad condition): Algeria, Bone, AFN 1, sandy soil under pepper, 25.09.1958, leg. P. Cassagnau (MNHNF).

Redescription. Body length (without antennae) $0.60-0.80 \mathrm{~mm}$. Colour yellowish on slides. Body shape cylindrical. Granulation of body uniform and fine, antennal bases are not marked. Antennal segment IV with subapical organite. Microsensillum on antennal segment IV is situated outside the triangle formed by a, b and c setae (Fig. 2B). Antennal III sense organ built of 4 guard setae, 5 papillae, 2 smooth sensory clubs and 2 small sensory rods. Postantennal sense organ small, ca. 3.8 times long as nearest pseudocellus with 9-10 finely granulated vesicles.
Dorsal pseudocellar formula 32/033/33333, ventral 2/000/00010; subcoxa 1 with one pseudocellus. Formula parapseudocelli ventrally and on subcoxa 1 invisible. Labium A type.

Dorsal chaetotaxy nearly symmetrical, poorly differentiated into macro- and microsetae. Sensilla short and broadened on dorsal side of body. Sensillar formula dorsally $1 / 011 / 111121$. Thoracic terga II and III with lateral microsensilla. Head with seta d0. Thoracic tergum I with $6+6$ setae. Abdominal tergum IV without medial seta m0. Abdominal tergum $\mathrm{V}$ with a3 as macrosetae, seta a2 absent and setae $\mathrm{m} 2$ present (Fig. 2G). Abdominal tergum VI with one medial seta $\mathrm{p} 0$. Anal spines rather small, about $0.60-0.80$ of inner edge of the claw III length. Subcoxa 1 of I, II, III pairs of legs with 2, 3, 4 setae respectively.

Ventral tube with 5-6+6 setae, and with $1+1$ setae at the base. Furca reduced to small area of fine granulation with posterior $2+2$ setulae arranged in a row.

Claws without inner teeth. Empodial appendage as long as inner edge of the claw, without basal lamella. Tibiotarsi with distal whorl composed of 7 setae. Male ventral organ absent.

Taxonomic remarks. The species was described by Cassagnau (1963) from Algeria on the basis of two specimens. Only a few details of the antennal sense organ, postantennal sense organ and dorsal chaetotaxy of some body segments are visible on the type material studied.

Among members of the obsiones group, O. obsiones is most similar to $O$. orienteuropeus sp.n. described below as both of the species are characterized by the same structure of antennal III sense organ (5 papillae and 4 guard setae). They clearly differ in details of body chaetotaxy, namely $O$. obsiones has $1+1$ setae at the base of ventral tube and a3 as macrosetae on abdominal tergum $\mathrm{V} ; O$. orienteuropeus $-0+0$ setae at the base of ventral tube and $\mathrm{a} 3$ as microsetae on abdominal tergum $\mathrm{V}$ (see also table).

Biology. O. obsiones is only known from the type locality (Algeria). Only females have been found.

\section{Onychiurus orienteuropeus sp.n.}

Figs $2 \mathrm{H}, 3 \mathrm{~A}-\mathrm{G}$.

Type material. Holotype: reproductive male on slide (N 3.13.9.1), Ukraine, Crimea, Sevastopol, Black Sea shore with graminifolious plants, $300 \mathrm{~m}$ to water edge, sandy soil, 05.09.1997, leg. S. Avdonin. Paratypes: 5 females on slides (N 3.13.9.2-4), the same place as holotype. Other material examined: 2 females on slide, Armenia, Karashamb village, mountain steppe, pasture, $1800 \mathrm{~m}$ a.s.l., soil under stone, 05.09.2000, leg. L. Narimanian. The material is preserved in the following collec- 

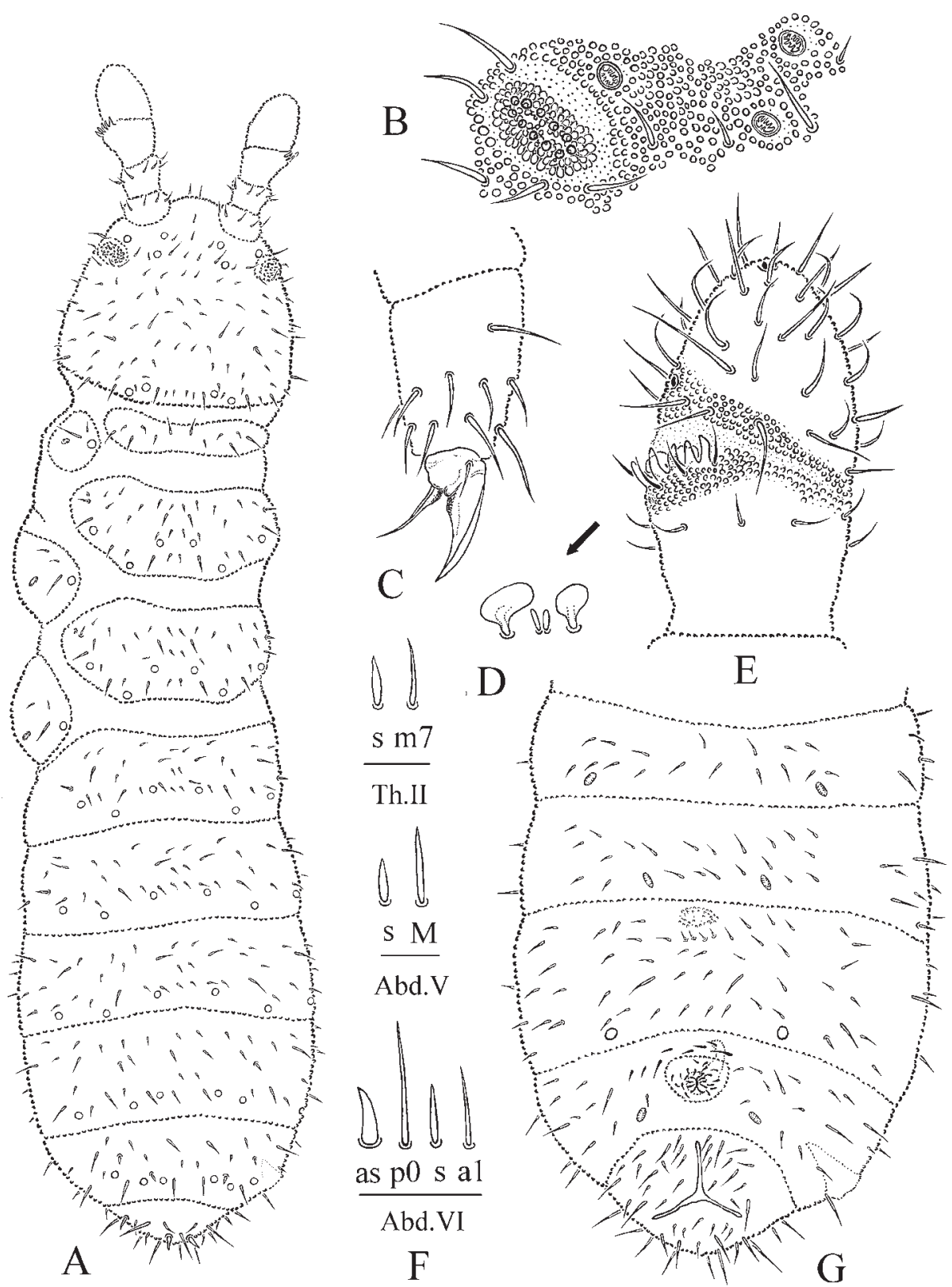

Fig. 3. Onychiurus orienteuropeus sp.n.

A - habitus and dorsal chaetotaxy, B - postantennal organ and anterior cephalic pseudocelli, C - tibiotarsal chaetotaxy and claw of leg III, D - sensory clubs and sensory rods, E - antennal segments III and IV with antennal III sense organ, F - dorsal ordinary setae (m7, M, p0. a1) and sensilla (s) set and anal spine (as), G - chaetotaxy of abdominal sterna II-VI.

Рис. 3. Onychiurus orienteuropeus sp.n.

A - общий вид и дорсальная хетотаксия, В — постантеннальный орган и ложные глазки в основании усиков, $\mathrm{C}$ - хетотаксия тибиотарзуса и коготок третей ноги, D - сенсорные колбочки и сенсорные палочки, E - III и IV сегменты усика с антеннальным органом, F - набор обычных дорсальных хет (m7, M, p0. a1) и сенсилл (s), а также анальный шип (as), G - хетотаксия II-VI абдоминальных стернитов. 
tions: SNHMU - holotype, 3 paratypes and other material; ZIWU -2 paratypes.

Etymology. The species name derived from the Latin words "orientalis" - eastern and "europeus" - European.

Diagnosis. Onychiurus orienteuropeus sp.n. has the same antennal III sense organ structure and similar chaetotaxy of abdominal tergum V ( $\mathrm{m} 2$ setae present but a 2 setae absent) as $O$. obsiones Cassagnau, 1963. The new species differs from $O$. obsiones in the absence of $1+1$ setae at the base of ventral tube and in the length of a3 setae on abdominal tergum $\mathrm{V}$ (see Table and Figs 2G, H).

Description. Body length (without antennae) 0.73-0.91 mm. Colour white. Granulation of body uniform and fine, antennal bases are not marked. Antennal segment IV with subapical organite. Microsensillum on antennal segment IV is situated outside the triangle formed by a, b and c chaetae (Fig. $3 \mathrm{E})$. Antennal III sense organ with 4 guard setae, 5 papillae, 2 smooth sensory clubs and 2 small sensory rods (Figs 3D, E). Postantennal sense organ small, ca. 4.1 times long as nearest pseudocellus with 10 11 finely granulated vesicles (Fig. 3B).

Dorsal pseudocellar formula $32 / 033 / 33333$, ventral 2/000/00010; all subcoxa 1 with one pseudocellus and one parapseudocellus (Figs 3A, G). Formula parapseudocelli ventrally: 0/000/111010 (Fig. 3G). Labium A type.

Dorsal chaetotaxy nearly symmetrical, clearly differentiated into macro- and microsetae (Fig. 3A). Sensilla on dorsal side of the body short and broadened. The shape and ratio of some sensilla, ordinary setae and anal spine are shown in Fig. 3F. Sensillar formula dorsally $1 / 011 / 111121$. Thoracic terga II and III with lateral microsensilla. Head with seta d0. Thoracic tergum I with $6+6$ setae. Abdominal tergum IV without medial seta $\mathrm{m} 0$. Abdominal tergum $\mathrm{V}$ with a3 as microsetae, seta $\mathrm{a} 2$ absent and setae $\mathrm{m} 2$ present (Fig. 2H). Abdominal tergum VI with one medial seta 0 . Anal spines rather short, about 0.56 0.80 of inner edge of the claw III length (Fig. 3F). Subcoxa 1 of I, II, III pairs of legs with 2, 3, 3 setae respectively (Fig. 3A).

Ventral chaetotaxy of abdominal sterna II-VI as on Fig. 3G. $0+0,1+1$ and $1+1$ ventral setae on pro-, meso- and metathorax respectively. Ventral tube with $6+6$ setae and without setae at the base. Furca reduced to small area of fine granulation with $2+2$ posterior setulae arranged in a single row (Fig. 3G).

Claws without inner teeth. Empodial appendage as long as inner edge of a claw, without basal lamella (Fig. 3C). Tibiotarsi with distal whorl composed of 7 setae. Male ventral organ absent.

Biology. O. orienteuropeus is bisexual species. It has been collected in dry habitats.

\section{Onychiurus jaceki sp.n.}

Figs 2J, 4A-H.

Type material. Holotype: reproductive male on slide (N 3.13.10.1), Kyrgyzstan, Issyk Kul District, Karakol area, Dzety Oguz, $2600 \mathrm{~m}$ alt., litter under juniper bushes, 11.06.2006, leg. R.J. Pomorski. Paratypes: 2 males and 2 females on slides (N 3.13.10.2), the same place as holotype. Other material examined: 1 female on slide, Kyrgyzstan, Issyk Kul District, Karakol area, Dzety Oguz, glade in the spruce forest, soil and litter, 11.06.2006, leg. R.J. Pomorski. The material is preserved in the following collections: SNHMU - holotype and 3 paratypes ( 2 males and 1 female); ZIWU -1 paratype (female).

Etymology. The species is dedicated to R. J. Pomorski who collected specimens of the new species from Kyrgyzstan.

Diagnosis. Onychiurus jaceki sp.n., is characterised by the presence of $7+7$ setae on thoracic tergum I, 9 setae in distal whorl on tibiotarsi, 5 papillae and 5 guard setae in antennal III sense organ, and by relatively strong anal spines. It has an isolated position in the obsiones group. It is similar to $O$. sarmaticus sp.n., described below, in its antennal III sense organ and chaetotaxy of abdominal tergum $\mathrm{V}$.

Description. Body length (without antennae) 0.85-0.95 mm. Colour white. Granulation of body uniform and fine, antennal bases is not marked. Microsensillum on antennal segment IV is situated outside the triangle formed by a, b and c setae (Fig. 4D). Antennal III sense organ built of 5 guard setae, 5 papillae, 2 smooth sensory clubs and 2 small sensory rods (Figs 4D, C). Postantennal sense organ small, ca. 3.8 times long as the nearest pseudocellus with 9-10 finely granulated vesicles (Fig. 4B).

Dorsal pseudocellar formula 32/033/33333, ventral 2/000/00010; all subcoxa 1 with one pseudocellus and one parapseudocellus (Figs 4A, H). Formula of parapseudocelli ventrally $0 / 000 / 111010$ (Fig. 4H). Labium of A type.

Dorsal chaetotaxy nearly symmetrical, clearly differentiated into macro- and microsetae (Fig. 4A). Sensilla relatively long and weakly differentiated on dorsal side of body. The shape and relative length of some sensilla, ordinary setae and anal spine as in Figs 4G, F. Sensillar formula dorsally 1/011/111121. Thoracic terga II and III with lateral microsensilla. Head with seta d0. Thoracic tergum I with $7+7$ setae. Abdominal tergum IV with medial seta m0. Setae a2 present and setae $\mathrm{m} 2$ absent on abdominal tergum $\mathrm{V}$ (Fig. 2J). Abdominal tergum VI with one medial seta p0. Anal spines rather strong, about $0.84-0.92$ of inner edge of the claw III length (Fig. 4F). Subcoxa 1 of I, II, III pairs of legs with 3, 4, 4 setae respectively (Fig. 4A).

Ventral chaetotaxy of abdominal sterna II-VI is given in Fig. 4H. 0+0, 1+1 and 1+1 ventral setae on 


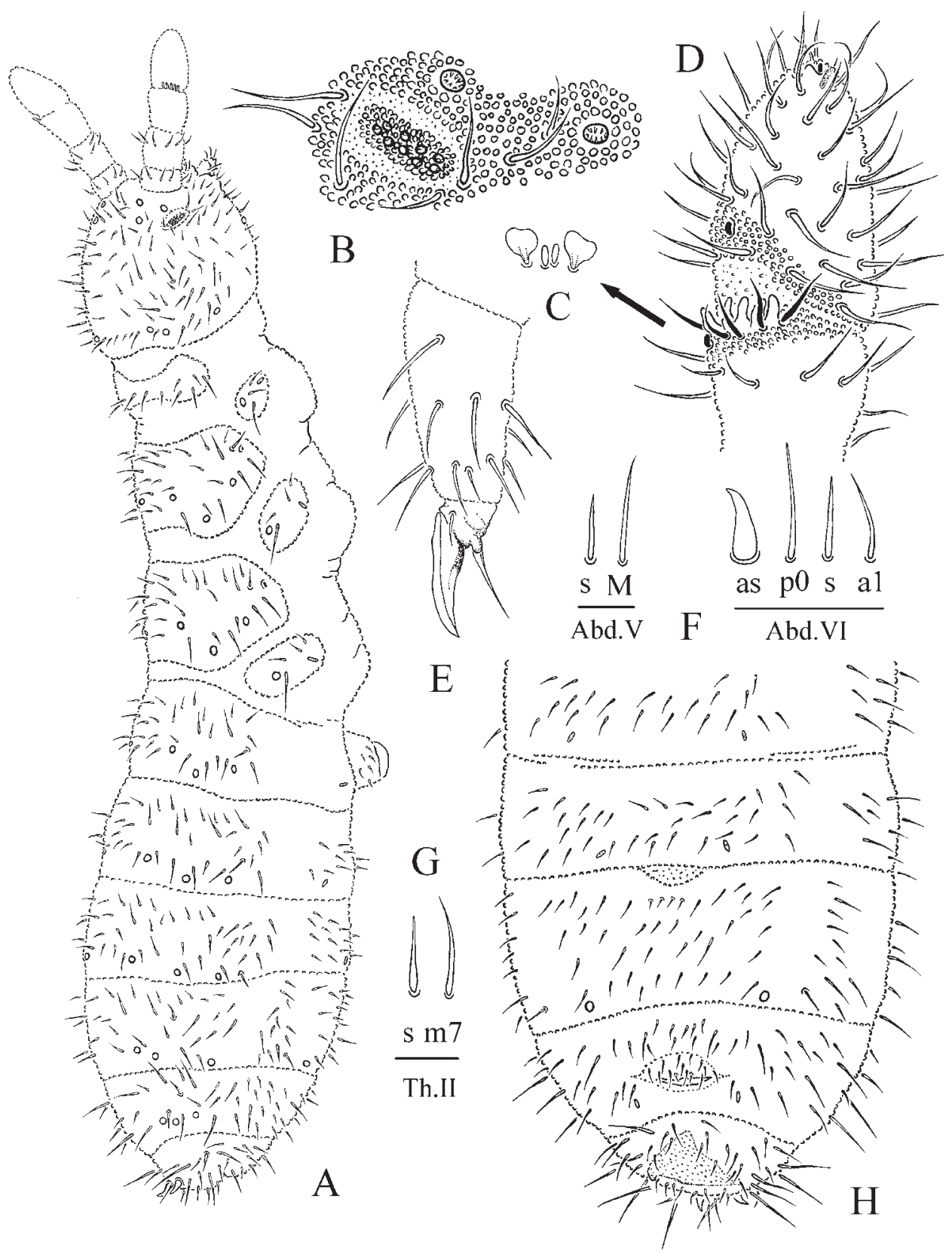

Fig. 4. Onychiurus jaceki sp.n.

A - habitus and dorsal chaetotaxy, B - postantennal organ and anterior cephalic pseudocelli, C - sensory clubs and sensory rods, D - antennal segments III and IV with antennal III sense organ, E - tibiotarsal chaetotaxy and claw of leg III, F, G — dorsal ordinary setae (m7, M, p0. a1) and sensilla (s) set and anal spine (as), H — chaetotaxy of abdominal sterna II-VI.

Рис. 4. Onychiurus jaceki sp.n.

A - общий вид и дорсальная хетотаксия, В - постантеннальный орган и ложные глазки в основании усиков, C - сенсорные колбочки и сенсорные палочки, D - III и IV сегменты усика с антеннальным органом, E хетотаксия тибиотарзуса и коготок третей ноги, $\mathrm{F}, \mathrm{G}$ - набор обычных дорсальных хет $(\mathrm{m} 7, \mathrm{M}, \mathrm{p} 0$. a1) и сенсилл (s), а также анальный шип (as), H - хетотаксия II-VI абдоминальных стернитов. 
pro-, meso- and metathorax respectively. Ventral tube with $6+6$ laterobasal setae and without setae at the base. Furca reduced to small area of fine granulation with $2+2$ setulae posteriorly arranged in a single row (Fig. 4H).

Claws without inner teeth. Empodial appendage as long as inner edge of a claw, without basal lamella (Fig. 4E). Tibiotarsi with distal whorl composed of 9 setae. Male ventral organ absent.

Biology. O. jaceki is bisexual species. It was collected only in dry habitats of Issyk Kul Lake Basin.

\section{Onychiurus sarmaticus sp.n.}

Figs 2L, 5A-H.

Type material. Holotype - male on slide $(\mathrm{N}$ 3.13.11.1), Ukraine, Dnipropetrovs'k district, Novomoskovs'k, biological station of Dnipropetrovs'k State University, Samara River bank, steppe with Stippa sp., soil, 26.06.1985, leg. O. Makarova. Paratypes: 1 male and 2 females on slides, the same place as holotype (N 3.1311.2); 1 male on slide (N 3.13.11.3), Ukraine, Mykolajiv district, Jelanets', Jelanets'kyi Step Reservation, steppe, soil, 26.05.1998, leg. V. Rizun; 1 male on slide (N 3.13.11.4), Ukraine, Donets'k district, Kamiani Mohyly Reservation, steppe, soil, 23.10.1996, leg. O. Starostenko. The material is preserved in the following collections: SNHMU - holotype and 4 paratypes (3 males and 1 female); ZIWU - 1 paratype (1 female).

Etymology. The species name is derived from Sarmatia, the ancient name of the region of SouthEast Europe between the Volga and Vistula Rivers.

Diagnosis. Onychiurus sarmaticus sp.n. differs from all members of obsiones group in having 1+1 pseudocelli on abdominal sternum $\mathrm{V}$. The presence of 5 guard setae in antennal III sense organ, the same type of chaetotaxy on abdominal tergum $\mathrm{V}$ and on subcoxa 1 of legs I, II, III place it close to $O$. jaceki sp.n. (see also Table).

Description. Body length (without antennae) $0.67-0.77 \mathrm{~mm}$. Colour white. Granulation of body uniform and fine, antennal bases not marked. Antennal segment IV with subapical organite. Microsensillum on antennal segment IV located outside the triangle formed by a, b and c chaetae (Fig. 5E). Antennal III sense organ with 5 guard setae, 5 papillae, 2 smooth sensory clubs and 2 small sensory rods (Figs 5D, E). Postantennal sense organ small, ca. 3.4 times long as nearest pseudocellus with $8-10$ finely granulated vesicles (Fig. 5B).

Pseudocellar formula dorsally: 32/033/33333; ventrally: 2/000/00011; all subcoxa 1 with one pseudocellus and one parapseudocellus (Figs 5A, H). Formula ventral parapseudocelli 0/000/111001 ${ }^{\mathrm{m}}$ (Fig. 5H). Labium of type A.

Dorsal chaetotaxy nearly symmetrical, poorly differentiated into macro- and microsetae (Fig. 5A). Sensilla relatively short and broadened on dorsal side of body. The shape and relative length of some sensilla, ordinary setae and anal spine presented in Figs 5F, G. Dorsal sensillar formula 1/011/111121. Thoracic terga II and III with lateral microsensilla. Head with seta d0. Thoracic tergum I with $6+6$ setae. Abdominal tergum IV with medial seta m0. Setae a2 present and setae $\mathrm{m} 2$ absent on abdominal tergum $\mathrm{V}$ (Fig. 2L). Abdominal tergum VI with one medial seta p0. Anal spines rather short, about as long as $0.57-0.85$ of inner edge of the claw III (Fig. 5G). Subcoxa 1 of I, II, III pairs of legs with 3, 4, 4 setae respectively (Fig. 5A).

Ventral chaetotaxy of abdominal sterna II-VI as on Fig. 5H. 0+0, 1+1 and 1+1 ventral setae on pro-, meso- and metathorax respectively. Ventral tube with $6+6$ setae and without setae at the base. Furca reduced to small area of fine granulation with $2+2$ setulae posteriorly arranged in a single row (Fig. $5 \mathrm{H}$ ).

Claws without inner teeth. Empodial appendage as long as inner edge of the claw, without basal lamella (Fig. 5C). Tibiotarsi with distal whorl composed of 7 setae. Male ventral organ absent.

Biology. O. sarmaticus is bisexual species. It has been collected only in dry habitats. It is probably associated with steppe communities of South-East Europe.

KEY TO THE SPECIES OF OBSIONES GROUP OF $O_{N Y-}$ CHIURUS

1. Antennal III organ with 4 papillae (Fig. 2E) ... 2 - Antennal III organ with 5 papillae (Fig. 5E) .... 3

2. Formula of parapseudocelli on abdominal sterna as 111000 , microsensillum on antennal segment IV is situated in the triangle formed by $a, b$ and c chaetae (Figs 1K, 2D) ............ O. vtorovi Martynova, 1976 (Kyrgyzstan, Russia: Tuva)

- Formula of parapseudocelli on abdominal sterna as $111011^{\mathrm{m}}$, microsensillum on antennal segment IV situated outside the triangle formed by a, b, c chaetae (Figs 2B, F) ... O. darii Pomorski, 1998 (Bulgaria, Ukraine)

3. Thoracic tergum I with $7+7$ setae, distal whorl on tibiotarsi composed of 9 setae (Figs 4A, E) ...... .................... jaceki sp.n.(Kyrgyzstan)

- Thoracic tergum I with 6+6setae, tibiotarsi with distal whorl composed of 7 setae (Figs 3A, C) ........................................... 4

4. Formula of pseudocelli on abdominal sterna as 00011, antennal III organ with 5 guard setae (Figs 5E, H) ...... O. sarmaticus sp.n. (Ukraine)

- Formula of pseudocelli on abdominal sterna as 00010, antennal III organ with 4 guard setae (Figs 3E, G)

6 . Ventral tube with $1+1$ setae at base, abdominal tergum V with a3 as macrosetae (Fig. 2G) .... .......... O. obsiones Cassagnau, 1963 (Algeria) 


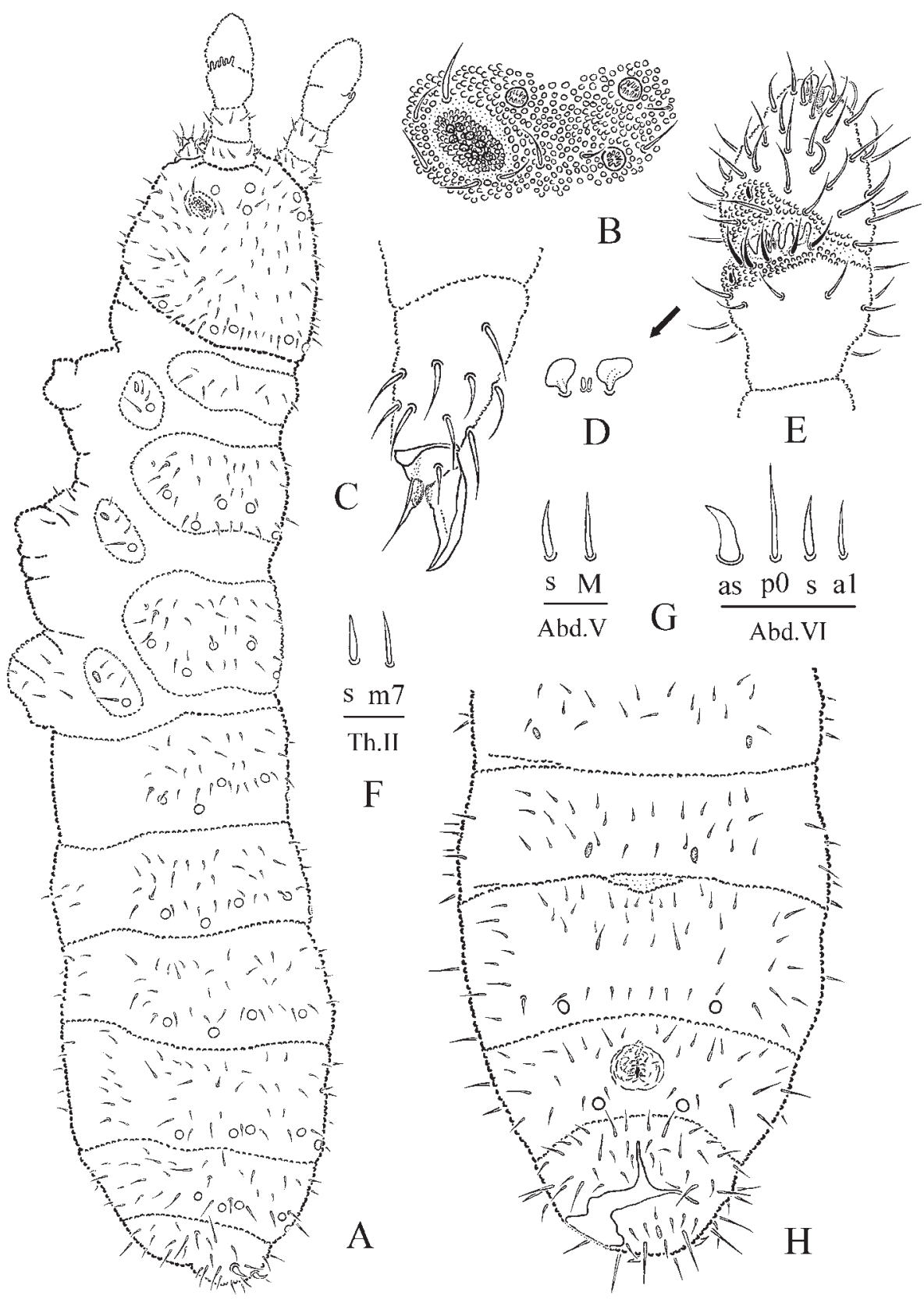

Fig. 5. Onychiurus sarmaticus sp.n.

A - habitus and dorsal chaetotaxy, B - postantennal organ and anterior cephalic pseudocelli, C - sensory clubs and sensory rods, D - antennal segments III and IV with antennal III sense organ, E - tibiotarsal chaetotaxy and claw of leg III, F, G - dorsal ordinary setae (m7, M, p0. a1) and sensilla (s) set and anal spine (as), H — chaetotaxy of abdominal sterna II-VI.

Рис. 5. Onychiurus sarmaticus sp.n.

A - общий вид и дорсальная хетотаксия, В - постантеннальный орган и ложные глазки в основании усиков, C - сенсорные колбочки и сенсорные палочки, D - III и IV сегменты усика с антеннальным органом, E хетотаксия тибиотарзуса и коготок третей ноги, $\mathrm{F}, \mathrm{G}$ - набор обычных дорсальных хет (m7, M, p0. a1) и сенсилл and sensilla (s), а также анальный шип (as), H - хетотаксия II-VI абдоминальных стернитов. 
- Ventral tube lacking setae at base, abdominal tergum $\mathrm{V}$ with a3 as microsetae (Fig. 2H) ..... O. orienteuropeus sp.n. (Ukraine, Armenia)

\section{Acknowledgments}

I am indebted to the following persons for the loan of the types and other materials and for the detailed information: Prof. Romuald J. Pomorski (Zoological Institute of Wroclaw University, Poland); Dr. Mikhail Potapov (Moscow State Pedagogical University); Dr. Anatoly Babenko and Dr. Sophya Stebaeva (Severtsov Institute of Ecology and Evolution, Moscow) and Prof. Louis Deharveng (Museum of Natural History, Paris). The work was supported by cooperative programmes between Russian and Ukrainian Academies of Sciences and also between Wroclaw University (Poland) and State Natural History Museum of Ukrainian National Academy of Sciences (L’viv).

\section{References}

Bellinger P.F., Christiansen K.A., Janssens F. 1996-2008. Checklist of the Collembola of the World. http:// www.collembola.org

Cassagnau P. 1963. Les Collemboles d'Afrique du Nord avec une étude de quelques espéces du Nord-Constantinois // Bulletin de la Société d'histoire naturelle de Toulouse. T.98. No.1-2. P.197-206.

Gervais P. 1841. Designation of Type and Description of Genus Onychiurus // Écho du Monde Savant. T.8. P.372.

Pomorski R.J. 1998a. Onychiurinae of Poland (Collembola: Onychiuridae) // Genus, BS (Suppl.). Biologica Silesie. Wroclaw. 201 p.

Pomorski R.J. 1998b. New Onychiurinae from Bulgaria and Turkey (Collembola: Onychiuridae) // Polish Journal of Entomology. Vol.67. P.3-11.

Vtorov P.P., Martynova J.F. 1976. [Microarthropods of the arid regions in the Issyk-Kul Lake Basin] // Zoologicheskij Zhurnal. Vol.55. No.7. P.1103-1107 [in Russian, with English summary].

Weiner W.M. 1996. Generic revision of Onychiurinae (Collembola: Onychiuridae) with cladistic analisis // Annales de la Société Entomologique de France (N. S.). T.32. No.2. P.163-200. 